\title{
Pengaruh Jenis Bonggol dan Konsentrasi Ba terhadap Pertumbuhan Vegetatif $P$ pada Tanaman Pisang Kepok Manado
}

\section{Effect From Kind of Hump and Ba Concentrate to Vegetative Growth of Banana Plant Manado Kepok Variety}

\author{
Angga Sukowardana ${ }^{1}$ Kushendarto $^{2}$ dan Rugayah ${ }^{2}$ \\ ${ }^{1}$ Mahasiswa Jurusan Agroteknologi, Fakultas Pertanian Universitas Lampung \\ ${ }^{2}$ Dosen Jurusan Agroteknologi, Fakultas Pertanian Universitas Lampung, \\ Jln.Prof. Soemantri Brodjonegoro, No.1, Bandar Lampung 35145 \\ Korespondensi: anggasuko13@gmail.com
}

\begin{abstract}
This study aimed to (1) determined the effect of BA concentration on the growth of banana seedlings origin hump cleavage. (2) determined the effect of different origin banana weevil seedling growth and tuber production of tillers. (3) determined the effect of BA concentration on the growth of seedlings and saplings of origin hump hump production. This research has been carried out in January 2013 to April 2013 in the Integrated Field Laboratory, University of Lampung, Bandar Lampung. The design of the experiment using a randomized block design with 3 replications were once created as a test group. Grouping is done based on the size of the hump and time of observation. Arranged in a factorial design of treatment (4 $x 2$ ) consisting of two factors; The first factor is the concentration of benzyladenine (BA) consists of 4 levels of concentration are: 0, 50, 100, and $150 \mathrm{ppm}$. The second factor is the hump that comes from plants that have been producing, and tubers of plants are still puppies. The results showed: (1). Use of BA with a concentration of 50, 100 and 150 ppm had no significant effect on all the variables of observation. (2). Type tuber production yield better growth than puppies hump seen from the variable leaf length, root length, leaf width, number of roots, and the girth so it better be made for seedlings compared with seedling tubers. (3) Pemberian BA with various concentrations of either the production or hump hump tillers showed no difference in the growth of shoots.
\end{abstract}

Keywords: nursery, benzyladenine, hump production, hump tillers

Diterima: 30-12-2014: disetujui 23-10-2015

\section{PENDAHULUAN}

Pisang (Musa paradisiacal Linn) merupakan jenis buah yang umum ditemui di perkotaan sampai ke pelosok desa. Produktivitas pisang yang dikembangkan di masyarakat masih rendah, produktivitas buah pisang di Lampung hanya 10-15 ton.ha ${ }^{-1}$ sementara potensi produktivitasnya dapat mencapai 35-40 ton.ha ${ }^{-1}$. Kendala produksi pisang tersebut disebabkan teknik budidaya yang kurang tepat serta tingginya gangguan hama dan penyakit. Kendala tersebut dapat diatasi dengan penerapan teknologi teknik budidaya, penggunaan varietas unggul dan perbaikan varietas (Mulyani, 2008). 
Masyarakat umumnya menggunakan anakan pisang untuk perbanyakan, tetapi untuk mendapatkan bibit yang sehat sulit karena terbatas ketersediaannya. Perbanyakan pisang dengan cacahan atau pecahan bonggol merupakan salah satu teknik pembibitan yang mulai banyak dikembangkan. Kelebihan bonggol pisang antara lain, dapat menghasilkan bibit pisang dengan jumlah yang lebih banyak serta lebih sehat dibandingkan dengan anakan pisang.

Diketahui bahwa pemberian berbagai zat pengatur tumbuh (ZPT) penting dalam perbanyakan tanaman karena mampu merangsang pembentukan akar maupun tunas. Pemberian ZPT ini dapat diaplikasikan pada kondisi laboratorium maupun lapangan. ZPT yang digunakan untuk menumbuhkan tunas adalah dari golongan sitokinin. Sitokinin adalah hormon tumbuhan turunan adenin berfungsi untuk merangsang pembelahan sel dan diferensiasi mitosis, disintesis pada ujung akar dan ditranslokasi melalui pembuluh xilem. Sitokinin yang paling banyak digunakan dalam kultur jaringan, yaitu: kinetin, benziladenin (BA atau BAP), dan zeatin (Zulkarnain, 2009).

\section{METODE}

Penelitian ini dilaksanakan bulan Januari sampai April 2013 di laboratorium Lapangan Terpadu Universitas Lampung, Bandar Lampung. Rancangan perlakuan disusun secara faktorial $(4 \times 2)$ yang terdiri dari dua faktor; faktor pertama adalah konsentrasi Benziladenin $(\mathrm{P})$ terdiri dari 4 taraf konsentrasi yaitu: 0, 50, 100, dan 150 ppm. Faktor kedua adalah jenis bonggol yang berasal dari tanaman yang sudah pernah berproduksi (b2), dan bonggol dari tanaman yang masih anakan (b1). Rancangan percobaan menggunakan rancangan acak kelompok (RAK) dengan 3 kali ulangan yang sekaligus buat uji sebagai kelompok. Pengelompokan dilakukan berdasarkan ukuran bonggol dan waktu pengamatan. Analisis ragam dilakukan dengan menggunakan homogenitas ragam dan dilanjutkan uji Bartlet. Apabila menunjukkan perbedaan nyata maka dilanjutkan dilanjutkan dengan menggunakan Beda Nyata Terkecil atau BNT pada taraf 5\%.

\section{HASIL DAN PEMBAHASAN}

\section{Tinggi Tunas}

Jenis bonggol berpengaruh dalam meningkatkan tinggi tunas, sedangkan konsentrasi BA tidak berpengaruh pada tinggi tunas. Begitu juga tidak ada ketergantungan antara kedua peubah tersebut. Jenis bonggol produksi menghasilkan tinggi tunas 27,62 cm lebih tinggi dibandingkan dengan jenis bonggol anakan yaitu 20,26 cm (Gambar 1).

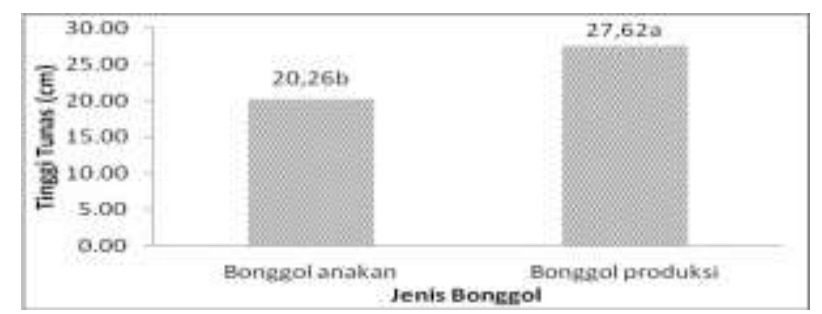

Gambar 1. Pengaruh jenis bonggol terhadap tinggi tunas pada perbanyakan tunas Pisang kepok Manado (Dua nilai tengah yang diikuti oleh huruf yang sama tidak berbeda nyata menurut uji BNT pada 5\%). BNT 2,13 


\section{Panjang Daun}

Jenis bonggol berpengaruh dalam meningkatkan panjang daun, sedangkan konsentrasi BA tidak berpengaruh terhadap jumlah daun dan tidak ada interaksi terhadap keduanya tersebut. Jenis bonggol produksi menghasilkan panjang daun $35,93 \mathrm{~cm}$ lebih panjang dibandingkan dengan jenis bonggol anakan yang menghasilkan panjang daun 24,93 cm (Gambar 2).

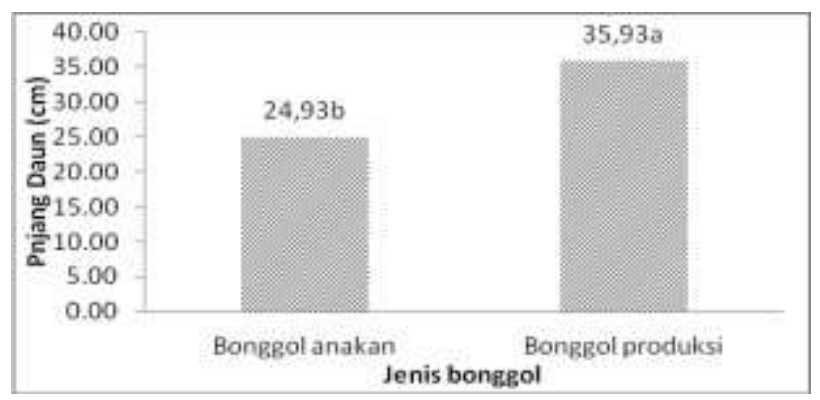

Gambar 2. Pengaruh jenis bonggol terhadap panjang daun pada perbanyakan tunas pisang kepok Manado. Nilai yang diikuti huruf yang sama tidak berbeda nyata berdasarkan uji BNT $0,05=2,8$

\section{Lebar Daun}

Jenis bonggol berpengaruh pada lebar daun, sedangkan konsentrasi BA tidak berpengaruh terhadap lebar daun dan tidak ada interaksi terhadap keduanya tersebut. Jenis bonggol produksi menghasilkan lebar daun 20,65 $\mathrm{cm}$ lebih lebar dibandingkan dengan jenis bonggol anakan yang menghasilkan lebar daun 14,34 cm (Gambar 3).

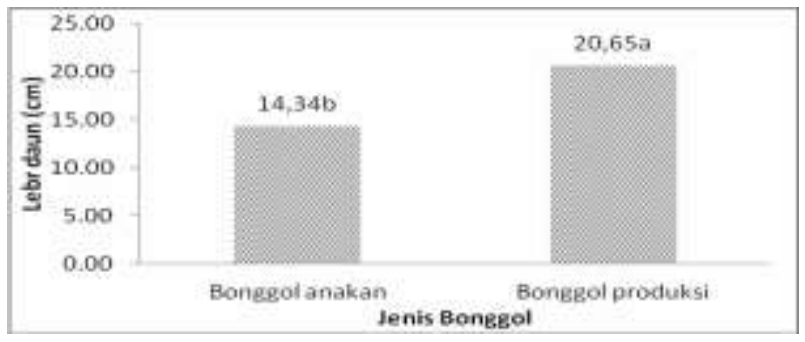

Gambar 3.Pengaruh jenis bonggol terhadap lebar daun pada perbanyakan tunas pisang kepok Manado. Nilai yang diikuti huruf yang sama tidak berbeda nyata berdasarkan uji BNT 0,05 $=1,80$

\section{Lingkar Batang}

Lingkar batang hanya dipengaruhi oleh jenis bonggol, sedangkan konsentrasi BA tidak berpengaruh terhadap lingkar batang dan tidak ada interaksi terhadap keduanya tersebut. Jenis bonggol produksi menghasilkan lingkar batang yang lebih besar yaitu 10,72 cm dibandingkan dengan jenis bonggol anakan yang hanya menghasilkan 9,43 cm (Gambar 4).

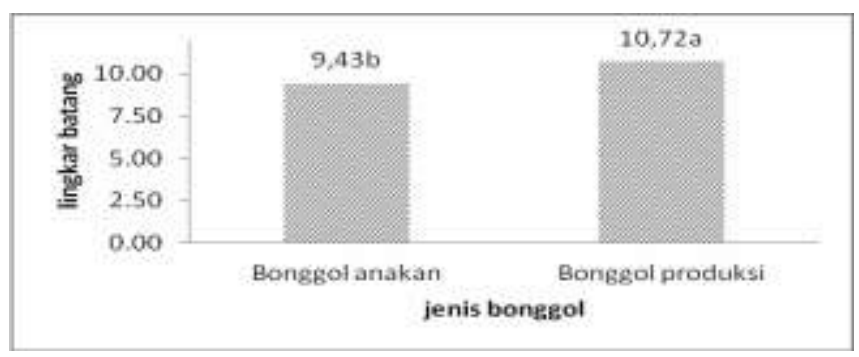

Gambar 4. Pengaruh jenis bonggol terhadap lingkar batang pada perbanyakan tunas pisang kepok Manado. Nilai yang diikuti huruf yang sama tidak berbeda nyata berdasarkan uji BNT $0,05=1,03$ 


\section{Jumlah Akar}

Jumlah akar pada pembibitan pisang kepok Manado dipengaruhi oleh jenis bonggol, sedangkan konsentrasi BA tidak berpengaruh dan tidak ada interaksi antara kedua perlakuan tersebut . Jumlah akar terbanyak dihasilkan dari jenis bonggol produksi yaitu 19,08 helai, lebih banyak dibandingkan dengan jenis bonggol anakan yang hanya menghasilkan akar sebanyak 8,08 helai(Gambar 5).

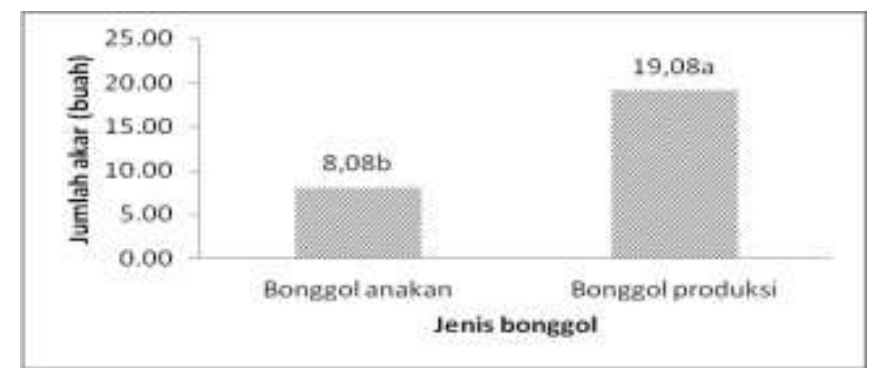

Gambar 5. Pengaruh jenis bonggol terhadap jumlah akar pada perbanyakan tunas pisang kepok Manado. Nilai yang diikuti huruf yang sama tidak berbeda nyata berdasarkan uji BNT $0,05=1,31$

\section{Panjang Akar}

Jenis bonggol berpengaruh dalam meningkatkan panjang akar, sedangkan konsentrasi BA tidak berpengaruh terhadap panjang akar dan tidak ada interaksi terhadap kedua perlakuan tersebut. Jenis bonggol produksi menghasilkan panjang daun 52,05 $\mathrm{cm}$ lebih panjang dibandingkan dengan jenis bonggol anakan yang menghasilkan panjang daun 32,28 $\mathrm{cm}$ (Gambar 6).

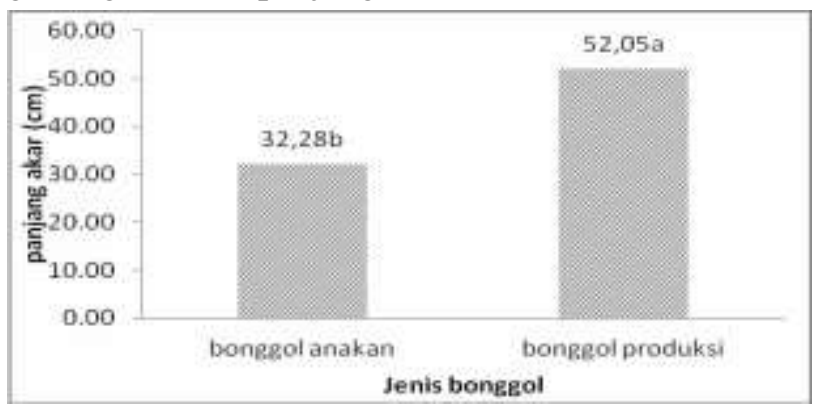

Gambar 6. Pengaruh konsentrasi BA terhadap panjang akar pada perbanyakan tunas pisang Kepok manado. Nilai yang diikuti huruf yang sama tidak berbeda nyata berdasarkan uji BNT $0,05=5,98$

Berdasarkan hasil pengamatan yang dilakukan pada perbanyakan tunas tanaman pisang kepok Manado didapatkan bahwa penggunaan Benziladenin (BA) dengan berbagai konsentrasi dan jenis bonggol tidak memberikan pengaruh yang berbeda nyata pada waktu muncul tunas, jumlah mata tunas dan jumlah daun. Begitu juga tidak ada interaksi antara kedua perlakuan tersebut pada semua variabel pengamatan. Tidak adanya pengaruh BA pada pertumbuhan tunas dikarenakan pemberian BA bergantung pada kemampuan penyerapan jaringan tanaman terhadap pemberian zat tersebut. Respons tanaman terhadap sitokinin tergantung pada jenis senyawa sitokinin yang diaplikasikan, spesies atau varietas tanaman, dan apakah tanaman yang dicobakan pada fase juvenile atau dewasa.

Bobot subang berpengaruh pada pertumbuhan tanaman gladiol selanjutnya, karena pertumbuhan tanaman gladiol ditentukan oleh jumlah makanan yang berasal dari subang. semakin besar ukuran subang berarti cadangan makanan untuk mendukung pertumbuhan juga semakin besar. Sama halnya dengan perbanyakan tanaman pisang menggunakan bonggol, cadangan makanan yang 
ada pada bonggol pisang digunakan sebagai bahan baku dan energi untuk menumbuhkan tunas dan akar.

Pada penelitian ini konsentrasi BA 50, 100, dan 500 ppm tidak berpengaruh nyata terhadap semua variabel pengamatan. Hal ini diduga karena cara aplikasi BA dengan penyemprotan pada bonggol pisang menjadi penyebab kurangnya respon bonggol terhadap pemberian BA. Hasil penelitian ini sesuai dengan penelitian Rabani (2009) bahwa pemberian BA pada konsentrasi 0, 25, dan 50 ppm yang diaplikasikan dengan penyemprotan pada bonggol pisang asal kultur jaringan tidak menunjukkan pengaruh nyata terhadap jumlah tunas lateral yang muncul pada bonggol pisang asal anakan. Hal ini menunjukkan bahwa pemberian BA pada konsentrasi 0-150 ppm tidak berpengaruh nyata terhadap jumlah tunas lateral yang muncul pada bonggol. Menurut Wattimena (1988), aplikasi ZPT pada tanaman dengan konsentrasi yang tepat dan cara yang tepat dapat memacu pertumbuhan tunas dan akar tanaman.

Penyebab lain yang menghambat respon tanaman terhadap pemberian BA adalah karena pemotongan pelepah yang kurang tepat sehingga sisanya masih menutupi mata tunas bagian dalam. Menurut Motiq (2011), pembelahan menjadi empat bagian mempunyai bonggol yang ukuran lebih besar sehingga penambahan BA dengan konsentrasi rendah sudah mampu meningkatkan jumlah tunas. Namun bila konsentrasi ditingkatkan maka jumlah tunas yang dihasilkan semakin rendah.

Menurut Lakitan (2011) pertumbuhan batang tanaman tidak membutuhkan sitokinin dalam konsentrasi yang tinggi atau membutuhkan sitokinin eksogen dalam konsentrasi yang rendah, karena kandungan endogen sudah mencukupi. Akibatnya penambahan sitokinin eksogen tidak lagi berpengaruh, bahkan dapat menghambat pertumbuhan karena konsentrasi sitokinin menjadi berlebih. ZPT tidak bekerja sendiri dalam mempengaruhi pertumbuhan dan perkembangan tanaman. Pada umumnya keseimbangan konsentrasi dari beberapa ZPT-lah yang akan mengontrol pertumbuhan dan perkembangan tanaman. Menurut Wattimena (1988), hormon berfungsi sebagai penggerak/pemicu reaksi-reaksi biokimia dan perubahan komposisi kimia di dalam tanaman yang mengakibatkan terbentuknya organ-organ tanaman, seperti; akar, tunas, batang, daun, bunga, dan lain sebagainya. Keberadaan auksin dengan konsentrasi tertentu berperan dalam merangsang dan memacu pertumbuhan tunas pucuk (Wattimena, 1988), Sedangkan sitokinin sangat aktif dalam merangsang pembelahan dan perbesaran sel tanaman (Gardner et al., 1985; Salisbury dan Ross (1995). Efektivitas zat pengatur tumbuh auksin maupun sitokinin eksogen bergantung pada konsentrasi hormon endogen dalam jaringan tanaman (Bhaskaran dan Smith, 1990)

Jenis bonggol berpengaruh nyata pada variabel pengamatan: tinggi tanaman, lebar daun, panjang daun, lingkar batang, panjang akar, jumlah akar. Pada semua variabel tersebut nilai rata-rata bonggol produksi lebih tinggi dibandingkan bonggol anakan. Hal ini menunjukan bahwa, bonggol produksi lebih efisien digunakan sebagai bibit dibandingkan dengan bonggol anakan. Selain itu jumlah cadangan makanan yang ada pada bonggol produksi lebih banyak daripada jumlah cadangan makanan yang ada pada bonggol anakan. Menurut Ulumudin (2011) pada saat pembibitan, tanaman belum mampu untuk melakukan fotosintesis sendiri sehingga tanaman yang akan tumbuh membutuhkan cadangan makanan yang diperoleh dari cadangan makanan yang ada pada bonggol.

Jenis bonggol berkolerasi dengan tinggi tanaman, lingkar batang, panjang akar, jumlah akar, dan lebar daun. Semakin besar ukuran bonggol (bonggol produksi) tanaman pisang semakin tinggi juga pertumbuhan tanaman pisang (tinggi tanaman, lingkar batang, panjang akar, jumlah akar, dan lebar daun). Menurut Motiq (2011), bahwa perbanyakan pisang Ambon Kuning melalui belahan bonggol, bonggol pisang yang memiliki bobot besar menghasilkan tinggi tunas, lingkar batang, jumlah 
daun, lebar daun, panjang daun, jumlah akar dan panjang akar yang lebih tinggi dibandingkan dengan bonggol pisang yang memiliki bobot kecil.

Hasil penelitian menunjukkan bahwa tidak terjadi interaksi pada semua variabel pengamatan. Hal ini terjadi karena beberapa kemungkinan. Kemungkinan pertama adalah cara pemberian BA yang kurang tepat. cara aplikasi BA dengan penyemprotan pada bonggol pisang menjadi penyebab kurangnya respon bonggol terhadap pemberian BA. Kemungkinan kedua adalah pemotongan batang pisang yang kurang pendek ke arah bonggol sehingga menyebabkan tertutupnya mata tunas bagian dalam. Kemungkinan ketiga adalah curah hujan yang tinggi dan terus menerus menyebabkan media tanam menjadi basah dan lembab.

Keadaan lembab tersebut akan memunculkan mikroorganisme jamur yang akan mengakibatkan tumbuhnya penyakit bagi tanaman. penyakit yang sering menyerang tanaman pisang adalah layu fusarium yang disebabkan oleh jamur Fusarium oxysporum f.sp.cubense. Pada fase patogenesis, patogen ini hidup di dalam tanah sebagai saprofit pada sisi tanaman. Patogen menyerang jaringan empulur batang melalui akar dan batang yang terserang akan kehilangan banyak cairan dan berubah menjadi warna coklat. Infeksi yang terjadi pada bonggol pisang akan mengganggu peroses penyerapan, transportasi air dan zat makanan di dalam tanah sehingga tanaman menjadi mati.

Dari 12 jenis bonggol anakan yang di tanam, 11 bonggol menghasilkan tunas yang tumbuh. Tetapi, tidak lebih baik dibandingkan jenis bonggol produksi, dari 12 jenis bonggol produksi, 11 bonggol menghasilkan tunas yang tumbuh. Pada setiap bonggol yang mampu menumbuhkan tunas lebih dari satu, rata-rata tunas yang pertama muncul mampu tumbuh dengan baik. Hal ini karena adanya kompetisi antar tunas pada satu bonggol dalam menggunakan cadangan makanan sebagai energi untuk pembentukan tunas. Hal Ini sesuai dengan hasil penelitian Ulumudin (2011) yang menyatakan bahwa perbanyakan pisang Ambon Kuning menghasilkan tunas lebih dari satu pada perlakuan BA 50 ppm, namun hanya tunas yang muncul pertama kali yang dapat bertahan hidup dan mampu tumbuh dengan baik. Tunas-tunas yang lain mati, hal ini diduga akibat persaingan yang kuat untuk bertahan hidup

\section{KESIMPULAN}

Penggunaan BA dengan konsentrasi 50, 100, dan 150 ppm tidak berpengaruh nyata terhadap semua variabel pengamatan. Jenis bonggol produksi menghasilkan pertumbuhan yang lebih baik dibandingkan bonggol anakan dilihat dari variabel panjang daun, panjang akar, lebar daun, jumlah akar, dan lingkar batang sehingga lebih baik di jadikan untuk bibit dibandingkan dengan bonggol anakan. Pemberian BA dengan berbagai konsentrasi baik pada bonggol produksi maupun bonggol anakan tidak menunjukkan adanya perbedaan pertumbuhan tunas.

\section{DAFTAR PUSTAKA}

Bhaskaran, S. and R. H. Smith. 1990. Regeneration in cereal tissue culture. A Review. Crop Sciencie. 30:1328-1336.

Gardner, F. F., P. Brent ., and L. M Roger. 1985. Physiology of Crop Plants.UI Press.Jakarta. 426 p.

Lakitan, B. 2011. Dasar-DasarFisiologiTumbuhan. Rajawali Pers. Jakarta. 206 Hal. 
Angga Sukowardana dkk; Pengaruh Jenis Bonggol dan Konsentrasi Ba terhadap Pertumbuhan Vegetatif ...

Mulyani, A. 2008. Potensi Dan Ketersediaan Lahan Untuk Pengembangan Kedelai Di Indonesia. http://www.pustaka.litbang.deptan.go.id.[19 September 2012].

Motiq, F. W. 2011. Pengaruh Konsentrasi Benziladenin (BA) dan Pembelahan Bonggol Terhadap Pertumbuhan Tunas Pada Perbanyakan Pisang Ambon Kuning Secara Konvensional. (Skripsi). Bandar lampung : Universitas Lampung. $72 \mathrm{hlm}$.

Rabani, B. 2009. Aplikasi Teknik Toping Pada Perbanyakan Benih Pisang (Musa paradisiacal.L) dari Benih Anakan dan Kultur Jaringan.(Skripsi). Bogor: Institut Pertanian Bandung 56 hlm.

Salisbury, F. B. dan C. W. Ross. 1995. Fisiologi Tumbuhan Jilid 2 (diterjemahkan dari: Plant Physiology, penerjemah : D.R. Lukman dan Sumaryono). Penerbit ITB. Bandung. 343 hal.

Ulumudin, A. 2011. Pengaruh Konsentrasi Benziladenin (BA) dan Media Tanam Terhadap Pertumbuhan Tunas Pada Perbanyakan Pisang Ambon Kuning Secara Konvensional. (Skripsi). Bandar lampung: Universitas Lampung. $72 \mathrm{hlm}$.

Wattimena, G. A. 1988. Zat Pengatur Tumbuh Tanaman. Pusat Antar Universitas Institut Pertanian Bogor. Bogor. 145 hal.

Zulkarnain. 2010. Dasar-dasar Hortikultura. Bumi Aksara. Jakarta. 336 hal. 